\title{
Cadmium's Effect on the Organization of Microtubular Cytoskeleton in Root Tips Cells of Salix matsudana Koidz
}

\author{
Jinhua Zou ${ }^{1,2}$, Gang Wang ${ }^{1 *}$, Jing $\mathrm{Ji}^{1 *}$, Jiayue Wang ${ }^{2}$, Jie Ouyang ${ }^{2}$, Binbin $\mathrm{Li}^{2}$ \\ ${ }^{1}$ School of Environmental Science and Engineering, Tianjin University, Tianjin 300072, P.R. China \\ ${ }^{2}$ Tianjin Key Laboratory of Animal and Plant Resistance, College of Life Sciences, Tianjin Normal University, \\ Tianjin 300387, P.R. China
}

Received: 3 June 2017

Accepted: 23 July 2017

\begin{abstract}
The toxic effects of Cd on microtubule (MT) organization in root tip cells of S. matsudana were investigated in the present study using tubulin immunolabeling and fluorescence microscopy. Cell damage and expression level of the SmTUA1 gene in the root tips were also examined by means of propidium iodide (PI) staining and quantitative real-time PCR (qRT-PCR) technology. The MT arrays were very sensitive to $\mathrm{Cd}$. At interphase, under $50 \mu \mathrm{mol} / \mathrm{L} \mathrm{Cd}$ treatment for $48 \mathrm{~h}$, some cortical MTs were discontinuous, inducing numbers of differently sized fragments. With increased $\mathrm{Cd}$ concentrations and duration of treatment, peripheral MTs appeared to be broken gradually, and the degree of disorder was enhanced. Spindle fibers even formed condensed MT at $10 \mu \mathrm{mol} / \mathrm{L} \mathrm{Cd}$ for $48 \mathrm{~h}$. During anaphase/telophase, there was a small part of MT absent, MT fibers were stuck to each other (even forming lumps) and could not form phragmoplast at $50 \mu \mathrm{mol} / \mathrm{L} \mathrm{Cd}$ for $48 \mathrm{~h}$. The cell damage of $S$. matsudana root tips increased with enhanced $\mathrm{Cd}$ concentrations and prolonged treatment time. Expression level of SmTUA1 analyzed by qRT-PCR further validated the results by indirect immunofluorescence staining. The data obtained here will be very useful to understand the mechanisms of Cd-induced cell toxicity.
\end{abstract}

Keywords: cadmium, cell damage, microtubule, mitosis, Salix matsudana Koidz

\section{Introduction}

Cadmium (Cd) has become one of the most harmful and widespread pollutants in water and soils caused by industrial emissions, the application of Cd-containing phosphate fertilizers, and municipal waste disposal [1]. It can easily be absorbed and accumulated in plant roots, and roots are the first organ in which plants contact

*e-mail: gangwanghjxy@163.com,jijing@tju.edu.cn this element in Cd-polluted soil [2]. The toxicity of $\mathrm{Cd}$ is associated with inhibitory interactions between numerous physiological and metabolic processes, such as interference in mitosis [3-4], toxicity to nucleoli structure [5-7], and influence on the organization of microtubular cytoskeleton and tubulin assembly/disassembly processes [7]. To prevent an excess of heavy metals in the metabolically active cytoplasm and organelles, the defence mechanisms come into operation, allowing for detoxification of harmful metal levels at the cellular level, including $\mathrm{Cd}$ exclusion, binding, and precipitation in the 
cell wall and/or compartmentalization in vacuoles [8-11]. Although there are some reports indicating that root tips play a major role in heavy metal perception and response $[3,12]$, the mechanism concerning plant root growth inhibition is still poorly understand.

Microtubules (MTs) - a key component of the eukaryotic cytoskeleton - play a central role in diverse activities such as cell division, cell expansion, cell differentiation, cytoplasmic organization, and intracellular motility [3-4]. The movement of chromosome and vesicle transport in secretion, prediction of the alignment of the cell plate, and orientation of the cellulose wall microfibrils are, to varying degrees, mediated by MTs [4]. Cytoplasmic MTs can change their orientation in response to various external and internal stimuli $[3-4,13]$. The destroyed MTs could not complete the cell cycle, meaning that chromosomes could not divide properly, leading to chromosome aberration. The hypersensitivity of the MT cytoskeleton might be a useful and simple parameter for estimating environmental stress intensity [3-4, 14].

Plants have evolved a large heterogeneity in the number of $\alpha$ - and $\beta$-tubulins genes, and different plants possess diverse sets of such genes [15-16]. Current knowledge indicates that plants can draw on a wide repertoire of genes for $\alpha$ - and $\beta$-subunits [17]. It is clear that the expression of some tubulin genes is likely related to precise functions. For example, the pollen-specific tubulin TUA1 of Picea wilsonii, when expressed in Arabidopsis, induces a high germination rate and increases the pollen tube growth rate [18]. In Populus, some $\alpha$-genes (such as TUA1 and TUA5) are highly expressed in woody tissues under conditions of increased cellulose synthesis [19]. During maize root development, four $\alpha$-tubulin and six $\beta$-tubulin isoforms were identified, the $\alpha 1$ and $\alpha 4$ isoforms predominate in dividing tissues (such as the root apex) while the $\alpha 2, \alpha 3$, and $\alpha 4$ isoforms are more abundant in mature tissues (differentiated roots). Sui et al. [20] investigated that eight members in $\alpha$-tubulin family in $S$. matsudana. The tubulins are evolutionarily conserved and highly dynamic processes, therefore it is very likely that they play crucial functions in the eukaryotic cells [16].

Willow, a fast-growing woody plant developing an extensive root system and large biomass, has strong resistance to heavy metals and is not linked to the food chain [21-23]. It effectively absorbs heavy metal ions from polluted water or soil, and as a result it is widely cultivated and used for phytoremediation of heavy metalcontaminated land [24-26]. Among the different willow species, commonly cultivated Salix matsudana Koidz. is a deciduous fast-growing tree native to China [2, 27]. Some studies concerned with its physiological and biochemical responses under Cd stress were reported, indicating that a few clones of $S$. matsudana have high heavy metal tolerance [2, 23, 28-29]. However, no studies on toxic effects of $\mathrm{Cd}$ on the microtubule organization in the root tips of $S$. matsudana have been reported. With the aim of contributing to understanding the mechanisms of $\mathrm{Cd}$-induced cell toxicity, the effects of $\mathrm{Cd}$ on the microtubule organization in root tip cells of $S$. matsudana was investigated using tubulin immunolabeling and fluorescence microscopy. Cell damage and TUA gene in the root tips were also examined by means of propidium iodide (PI) staining and quantitative real-time PCR (qRT$\mathrm{PCR})$ technology in the present investigation.

\section{Material and Methods}

\section{Plant Cultivation and Growth Conditions}

Plant materials were propagated from branches of the same adult mother plants, one clone of $S$. matsudana. Cuttings of the same size $(20 \mathrm{~cm}$ in height $)$ were placed on a polystyrol plate in a pot containing $10 \mathrm{~L}$ modified half-strength Hoagland's nutrient solution comprising $5 \mathrm{mmol} / \mathrm{L} \mathrm{Ca}\left(\mathrm{NO}_{3}\right)_{2}, 5 \mathrm{mmol} / \mathrm{L} \mathrm{KNO}_{3}$, $1 \mathrm{mmol} / \mathrm{L} \mathrm{KH}_{2} \mathrm{PO}_{4}, 50 \mu \mathrm{M} \mathrm{H}_{3} \mathrm{BO}_{3}, 1 \mathrm{mmol} / \mathrm{L} \mathrm{MgSO}_{4}$, $4.5 \mu \mathrm{mol} / \mathrm{L} \mathrm{MnCl}_{2}, 3.8 \mu \mathrm{mol} / \mathrm{L} \mathrm{ZnSO}_{4}, 0.3 \mu \mathrm{mol} / \mathrm{L}$ $\mathrm{CuSO}_{4}, \quad 0.1 \mu \mathrm{mol} / \mathrm{L} \quad\left(\mathrm{NH}_{4}\right)_{6} \mathrm{Mo}_{7} \mathrm{O}_{24}$, and $10 \mu \mathrm{mol} / \mathrm{L}$ Fe-EDTA at $\mathrm{pH}$ 5.5. After the roots were about $1 \mathrm{~cm}$, they were divided into four groups, and three of these groups were stressed with different concentrations of $\mathrm{Cd}$ $(10,50$, and $100 \mu \mathrm{mol} / \mathrm{L})$. Cd was provided as $\mathrm{Cd}\left(\mathrm{NO}_{3}\right)_{2}$. $\mathrm{Cd}$ solutions were prepared in deionized water and were added to full-strength Hoagland's nutrient solution. Full-strength Hoagland's solution without Cd was used for control plants. The plants treated with different concentrations of $\mathrm{Cd}$ were maintained under natural light conditions, $25 \pm 1{ }^{\circ} \mathrm{C}, 50 \pm 1 \%$ relative humidity, and a $12-\mathrm{h}$ day/night regime in an air-conditioned greenhouse. The nutrient solutions were aerated continuously.

\section{PI staining}

To observe the cell damage in root tip cells of $S$. matsudana induced by $\mathrm{Cd}, 10$ intact root tips exposed to different concentrations of $\mathrm{Cd}(0,10,50$, and $100 \mu \mathrm{mol} / \mathrm{L})$ for $1,3,6,9,12$, and $24 \mathrm{~h}$ were stained with PI in darkness at room temperature and then washed three times $(3 \times 10$ min) with the sodium phosphate buffer (PBS), according to the methods from Shi et al. (2016). The specimens were examined with a confocal laser scanning microscope (ECLIPSE 90i, Nikon Corporation, Tokyo, Japan) with excitation maximum at $535 \mathrm{~nm}$ and fluorescence emission maximum at $617 \mathrm{~nm}$. The fluorescence density was calculated using the "analyze and measure" function of the Image J software (NIH, Bethesda, MD, USA) from 10 intact root tips of $S$. matsudana woody cuttings - each treatment group under Cd stress.

\section{Immunofluorescence Staining}

Healthy and equal-sized $S$. matsudana specimens were selected for cytological study. When they measured approximately $0.6 \mathrm{~cm}$ in length, the roots were treated with Cd solutions of different concentrations (10, 50, and $100 \mu \mathrm{mol} / \mathrm{L}$ ) for 24, 48, 72, and $96 \mathrm{~h}$. Meristematic zones 
of 10 root tips from control and the Cd-treated batches were cut and fixed with $4 \%(\mathrm{w} / \mathrm{v})$ paraformaldehyde in PBS ( $\mathrm{pH} 7.0$ ) for $1.5 \mathrm{~h}$ in darkness at room temperature, and then washed with the same buffer three times $(3 \times 10$ $\min )$. Meristematic cells were digested for 50 min with a mixture of $2.5 \%$ cellulose and $2.5 \%$ pectolase at $37^{\circ} \mathrm{C}$ and then washed in PBS three times. They were squashed on slides and extracted in freshly prepared $1 \%(\mathrm{v} / \mathrm{v})$ Triton X-100 in PBS for 20 min until the slides dried. Then the cells were rinsed in PBS and incubated with the mouse monoclonal anti- $\alpha$-tubulin antibody (Sigma T-9026) diluted at $1 / 50$ in a moist airtight container for $1 \mathrm{~h}$ at $37^{\circ} \mathrm{C}$. After three washes in PBS for 10 min each, cells were incubated in secondary fluorescein isothiocyanate (FITC) sheep anti-mouse antibody (Sigma F-0257) diluted at 1:50, and the cells were incubated in the dark for $45 \mathrm{~min}$ at $37^{\circ} \mathrm{C}$. Repeated washing in PBS, nuclei were stained with 4', 6-diamidino-2-phenylindole (DAPI, Sigma) at a final concentration of $1 \mu \mathrm{g}$ per $1 \mathrm{~mL}$ for $15 \mathrm{~min}$ at room temperature. After washing $(3 \times 10 \mathrm{~min})$ in $\mathrm{PBS}$, the cells were mounted in antifade mounting medium. The slides were stored at $4^{\circ} \mathrm{C}$ in the dark until observed. The immunofluorescent specimens were examined with a Nikon ECLIPSE 90i confocal laser scanning microscope. An exciter at $408 \mathrm{~nm}$ and a barrier at $515 / 30 \mathrm{~nm}$ as well as an exciter at $488 \mathrm{~nm}$ and a barrier at 590/50 nm were used for DAPI and FITC staining, respectively. Image recording was done with proper software (EZ-C1 3.80) according to the manufacturer's instructions. Images were processed with Image-Pro Plus 6.0 and Photoshop 7.0.

\section{qRT-PCR Analysis of $S$. matsudana $\alpha$-tubulin 1 (SmTUA1) in Roots}

The root meristem zone of control and treatment groups exposed to 10,50 , and $100 \mu \mathrm{mol} / \mathrm{L}$ of $\mathrm{Cd}$ for 24 , 48, and $72 \mathrm{~h}$ were used for gene expression analysis of SmTAU1. Meristematic zones of 10 root tips from the control and the Cd-treated batches were cut and washed with deionized water. Total RNA was extracted using the easy spin Plant RNA Extraction Kit (Aidlab, China), and cDNA was reverse-transcripted using First-Strand Synthesis SuperMix (TransScript, China) according to the manufacturer's instructions. RNA integrity was verified by running agarose gel electrophoresis and detecting the three bands corresponding to ribosomal RNA 25S, $18 \mathrm{~S}$, and 5S. The extracted RNA was quantified with a NanoDrop $200^{\circ} \mathrm{C}$ Spectrophotometer (Biochrom, England) and stored at $-80^{\circ} \mathrm{C}$. Each treatment was replicated twice.

Every cDNA template for the qRT-PCR reaction with 7500 Real-Time PCR (Applied Biosystems, USA) was measured using a SYBR Select Master Mix (Applied Biosystems, USA). The program used for qRT-PCR was as follows: UDG activation at $50^{\circ} \mathrm{C}$ for $2 \mathrm{~min}$, Amplitaq fast DNA polymerase, up activation at $95^{\circ} \mathrm{C}$ for $2 \mathrm{~min}$, followed by 40 cycles of denaturation at $95^{\circ} \mathrm{C}$ for $15 \mathrm{sec}$ and annealing/extension at $50^{\circ} \mathrm{C}$ for $1 \mathrm{~min}$.
Table 1. Sequences of primers for qRT-PCR.

\begin{tabular}{|c|c|}
\hline Gene & Primers sequences (5' -3 ') \\
\hline \multirow{2}{*}{ SmTUA1 } & F: CCACTCAACCTCAGCATCAATT \\
\cline { 2 - 2 } & R: ATAGCAGCCAAACAAACACACT \\
\hline
\end{tabular}

The gene-specific forward and reverse primers and cDNA template were added to the SYBR Select Master Mix. Primers for the genes were designed by Primer 5.0 with gene sequences from GenBank in NCBI. The Populus trichocarpa nicotinamide adenine dinucleotide phosphate (NADPAH) gene was used as a reference gene. Primers designed for the SmTUA1 gene are detailed in Table 1. Real-time PCR experiments were conducted on the two biological replicates, with three technical replicates for each sample. Melting curves were used to assess amplification specificity. The relative quantities of the transcripts were analyzed using the comparative $\mathrm{Ct}$ method [38].

\section{Statistical Analysis}

Analysis of variance of the data was performed by using SPSS 15.0 version for Windows. For statistical analysis, one-way analysis of variance (ANOVA), and $t$-test were used to determine significance at $P<0.05$.

\section{Results}

\section{Effects of Cd on Root Growth}

The effects of $\mathrm{Cd}$ on the root growth of S. matsudana varied with different treatment times (Fig. 1). Compared with control, $\mathrm{Cd}$ had a stimulation effect at $10 \mu \mathrm{mol} / \mathrm{L}$ $\mathrm{Cd}$ and had no toxic effect at $50 \mu \mathrm{mol} / \mathrm{L} \mathrm{Cd}$ during the whole treatment process. At $100 \mu \mathrm{mol} / \mathrm{L} \mathrm{Cd}$ treatment, root length was inhibited significantly after 48 and $72 \mathrm{~h}$ of Cd stress $(P<0.05)$.

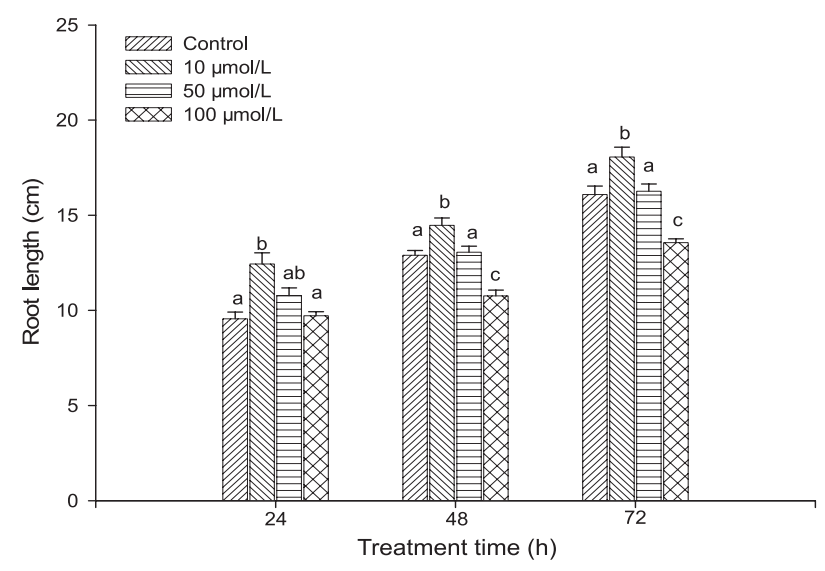

Fig. 1. Effects of different concentrations of $\mathrm{Cd}$ on root length of $S$. matsudana. Values with different letters (a, b, c, d) differ significantly from each other $(\mathrm{P}<0.05)$. 


\section{Effects of Cd on Cell Damage}

To visualize the damaged root tip cells induced by $\mathrm{Cd}$, the root tip cells of $S$. matsudana exposed to 10,50 , and $100 \mu \mathrm{mol} / \mathrm{L} \mathrm{Cd}$ for $0,1,3,6,12$, and $24 \mathrm{~h}$ were stained with PI. Red fluorescence was an indicator of cell damage as PI entered cells. The toxic effects of Cd on cell damage in root tips of $S$. matsudana varied with the different $\mathrm{Cd}$ concentrations and treatment times (Fig. 2). Very weak fluorescence was observed in control root tip cells (Figs 2A1-A3), suggesting there was nearly no cell damage in root tips during the plant growth period without $\mathrm{Cd}$ treatment. A low level of fluorescence intensity was observed in the cells stressed for $3 \mathrm{~h}$ at $10 \mu \mathrm{mol} / \mathrm{L} \mathrm{Cd}$, indicating that $\mathrm{Cd}$ could induce cell damage as early as $3 \mathrm{~h}$ at $10 \mu \mathrm{mol} / \mathrm{L} \mathrm{Cd}$ exposure (Fig. 2C1). Fluorescence intensity was more pronounced with prolonged exposure (Figs 2C1-F1). When S. matsudana were treated with 50 and $100 \mu \mathrm{mol} / \mathrm{L} \mathrm{Cd}$, the fluorescence intensity of the root tips became more intense (Figs 2C2-F3), especially in

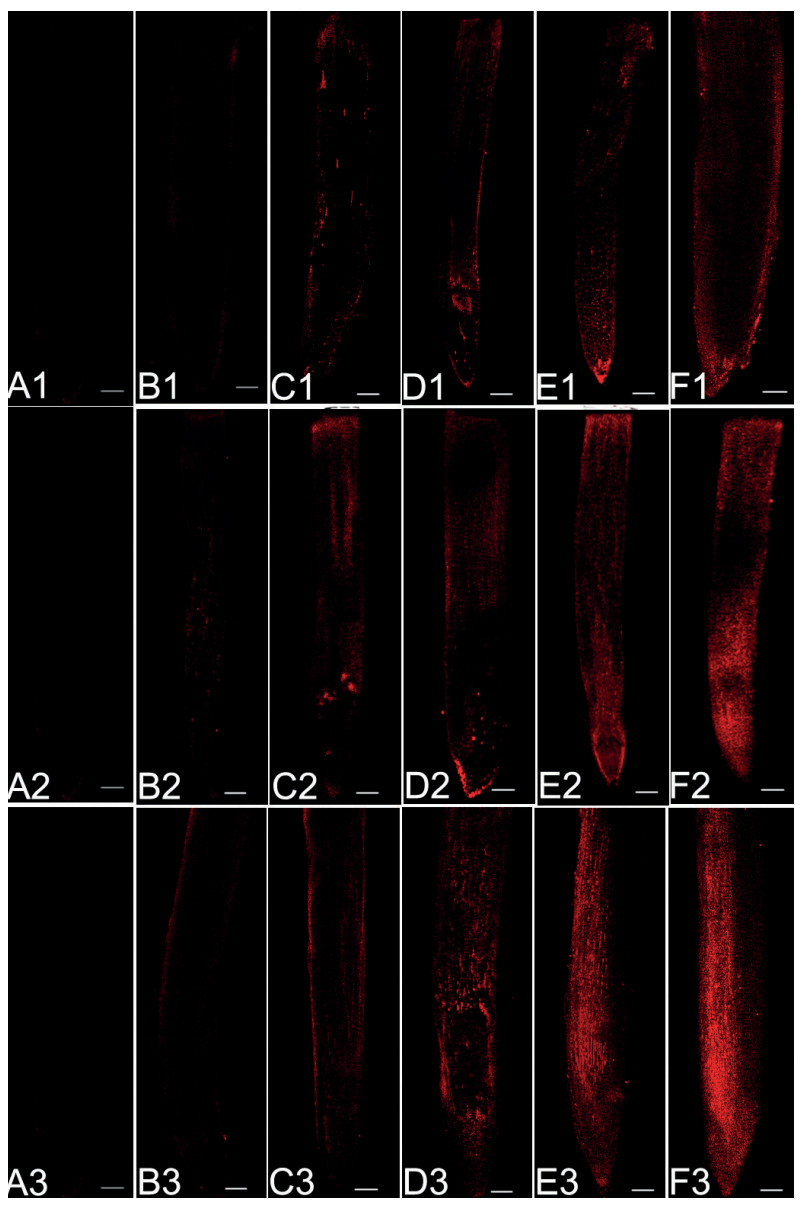

Fig. 2. PI fluorescence density in the root tip of $S$. matsudana treated with different concentrations of $\mathrm{Cd}(10,50$, and 100 $\mu \mathrm{mol} / \mathrm{L})$. A1, A2, and A3 were the dyeing results of control; B1$\mathrm{F} 1$ were the dyeing results of roots exposed to $10 \mu \mathrm{mol} / \mathrm{L} \mathrm{Cd}$ for $1,3,6,12$, and $24 \mathrm{~h}$; B2-F2 were the dyeing results of roots exposed to $50 \mu \mathrm{mol} / \mathrm{L} \mathrm{Cd}$ for $1,3,6,12$, and $24 \mathrm{~h}$; and B3-F3 were the dyeing results of roots exposed to $100 \mu \mathrm{mol} / \mathrm{L} \mathrm{Cd}$ for 1 , $3,6,12$, and $24 \mathrm{~h}$. (Bars $=10 \mu \mathrm{m})$.



Fig. 3. PI fluorescence density of the roots exposed to 10, 50, and $100 \mu \mathrm{mol} / \mathrm{L} \mathrm{Cd}$ for $1,3,6,12$, and $24 \mathrm{~h}$. Values with different letters $(\mathrm{a}, \mathrm{b}, \mathrm{c}, \mathrm{d})$ differ significantly from each other $(\mathrm{P}<0.05)$.

the apical meristem of 50 and $100 \mu \mathrm{mol} / \mathrm{L} \mathrm{Cd-treated} \mathrm{root}$ tips for $24 \mathrm{~h}$ (Figs 2F2, F3). Data from the fluorescence density analysis by Image $J$ software could confirm the findings (Fig. 3). The cell damage increased significantly with enhanced $\mathrm{Cd}$ concentrations and prolonged treatment times $(P<0.05)$.

\section{MT Arrays in the Cell Cycle of Control Root Meristem Cell}

The $S$. matsudana root meristem cells of the control group have a normal cell cycle, and typical MTs arrayed in each mitotic period were clearly found, indicating that the MTs were well labeled in these cells (Fig. 4). Periplasmic MTs during interphase of normal meristematic cells were abundant, dense, parallel to each other, and oriented perpendicular to the longitudinal axis of cell expansion (Fig. 4A1). In preprophase cells, the nuclear envelope remained intact, and MT gradually gathered
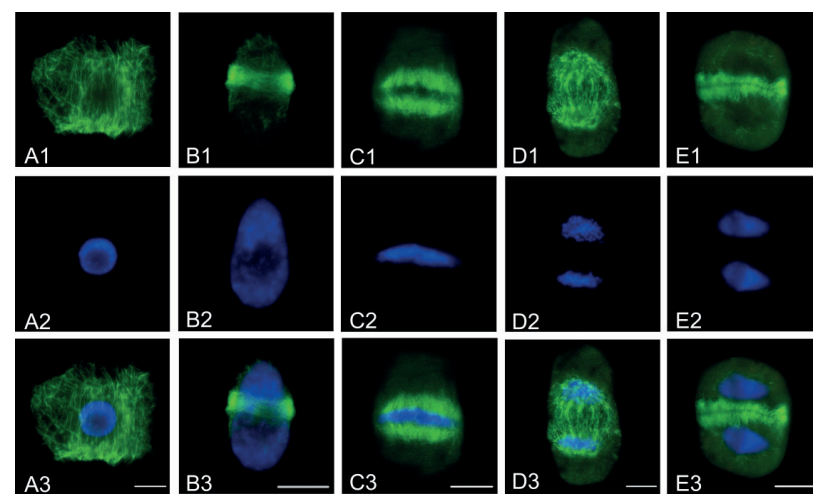

Fig. 4. Showing the organization of MT cytoskeleton in control cells. Tubulin immunol- abelling (A1-E1, green), DNA staining with DAPI (A2-E2, blue), and merged images (A3-E3): A) Interphase, B) Early prophase, C) Metaphase, D) Anaphase, and E) Telophase. $(\mathrm{Bar}=10 \mu \mathrm{m})$. 
to the equatorial plate and formed a girdle-shaped preprophase band around the nucleus, which was very bright and easy to observe under a confocal laser scanning microscope, and was a significant sign of the cell into the prophase of mitosis (Fig. 4B1). In the metaphase cells, MT filaments were arranged neatly on both sides of the equatorial plate to form spindle and phragmoplast (Fig. 4C1). The spindle MTs were linked to the centromeres of chromosomes and segregated the sister chromatids to the opposite poles (Figs 4D1-D3). In anaphase/telophase cells, the spindle MTs disappeared, and the phragmoplast MTs were assembled in both sides of the developing cell plate parallel to the equator plate, expanded until it contacted the parent cell walls (Figs 4E1-E3).

\section{Effects of Cd Stress on Interphase MT Arrays in Root Meristem Cells}

The MT arrays were very sensitive to $\mathrm{Cd}$, and their sensitivity depends on the $\mathrm{Cd}$ concentration and the duration of treatment. At $10 \mu \mathrm{mol} / \mathrm{L} \mathrm{Cd}$ treatment for $24 \mathrm{~h}$, the peripheral MTs appeared to have a slight bend, and most of the MTs were oriented perpendicular to the longitudinal axis of the cell (Fig. 5A1). With treatment time prolonged to $48 \mathrm{~h}$, the cortical MTs appeared to have obvious alterations, and most of the MTs were no longer arranged in a parallel direction, orderly, and appeared a few fragments (Figs 5B1, C1). At $50 \mu \mathrm{mol} / \mathrm{L} \mathrm{Cd}$ for $48 \mathrm{~h}$, more cortical MTs were discontinuous, inducing numbers of differently sized fragments at the cell periphery (Figs 5D1-D3). A large number of peripheral MTs appeared to be broken, and the degree of disorder was enhanced after $100 \mu \mathrm{mol} / \mathrm{L} \mathrm{Cd}$ treatment for $48 \mathrm{~h}$ (Figs 5E1-E3). Effects of Cd on cellular MT array integrity could damage cells and even induce cell death. The proportion of abnormal MTs increased with increasing $\mathrm{Cd}$ concentration and prolonged exposure.

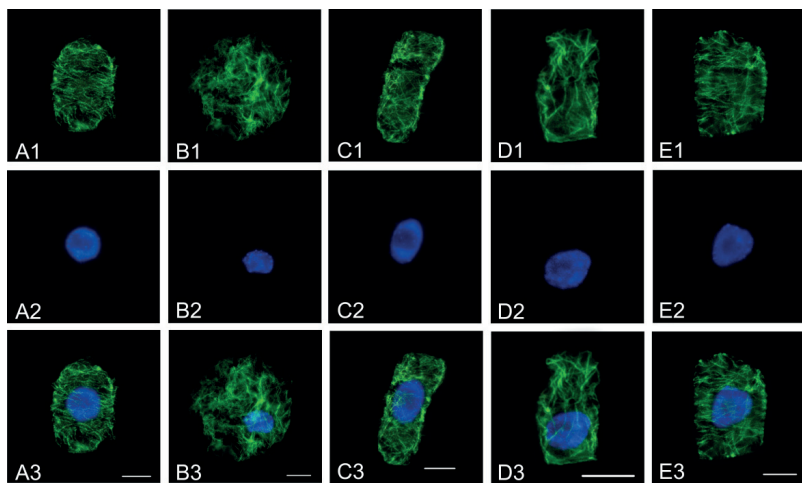

Fig. 5. Cd effects on the organization of MT cytoskeleton in interphase cells. Tubulin immunolabelling (A1-E1, green), DNA staining with DAPI (A2-E2, blue), and merged images (A3-E3) of treated root tip cells. A) $10 \mu \mathrm{mol} / \mathrm{L} \mathrm{Cd}, 24 \mathrm{~h}$; B-C) $10 \mu \mathrm{mol} / \mathrm{L}$ $\mathrm{Cd}, 48 \mathrm{~h}$; D) $50 \mu \mathrm{mol} / \mathrm{L} \mathrm{Cd}, 48 \mathrm{~h}$; and E) $100 \mu \mathrm{mol} / \mathrm{L} \mathrm{Cd}, 48 \mathrm{~h}$. $(\mathrm{Bar}=10 \mu \mathrm{m})$.
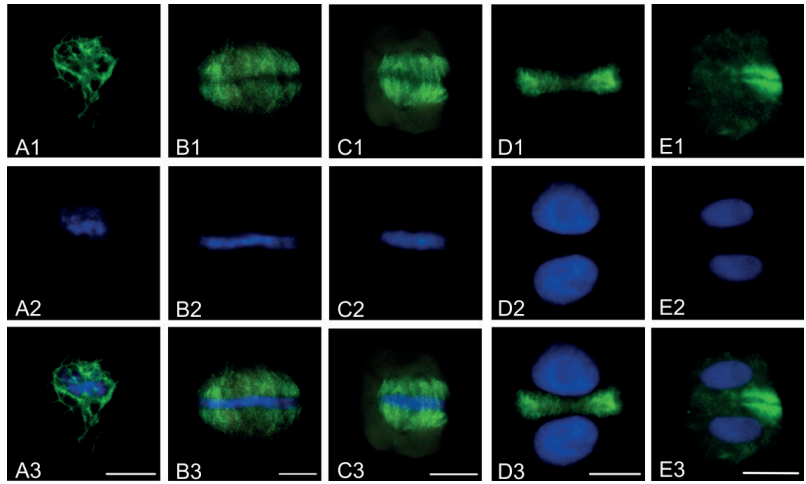

Fig. 6. Cd effects on the organization of MT cytoskeleton in mitotic cells. Tubulin immunolabelling (A1-E1, green), DNA staining with DAPI (A2-E2, blue), and merged images (A3-E3). A-B) $10 \mu \mathrm{mol} / \mathrm{L} \mathrm{Cd}, 24 \mathrm{~h}$; C-D) $10 \mu \mathrm{mol} / \mathrm{L} \mathrm{Cd}, 48 \mathrm{~h}$; and E) $50 \mu \mathrm{mol} / \mathrm{L} \mathrm{Cd}, 96 \mathrm{~h} .(\mathrm{Bar}=10 \mu \mathrm{m})$.

\section{Effects of Cd Stress on Mitotic MT Arrays in Root Meristematic Cells}

Cd stress affected mitotic spindle MT arrays in $S$. matsudana root meristem cells obviously by immunofluorescence labeling (Fig. 6). In the present investigation, MT arrangement was found to be closely related to chromosomal aberrations during mitosis under $\mathrm{Cd}$ stress. In some cells exposed to $10 \mu \mathrm{mol} / \mathrm{L} \mathrm{Cd}$ for $24 \mathrm{~h}$, mitotic spindle MTs lost their organization and were randomly oriented and scattered in cells (Figs 6A1, A3) and sister chromatids could not be moved to the cell poles, resulting in the formation of c-mitosis (Figs 6A2, A3). We also found that chromosomes at metaphase could be normally distributed in the central part of the cell (Fig. 6B2) under Cd stress, spindle fibers were orderly arranged on the equatorial plate on both sides, but formed fragments slightly even condensed MT (Figs 6B1, B3). With treatment time prolonged to $48 \mathrm{~h}$ at $10 \mu \mathrm{mol} / \mathrm{L} \mathrm{Cd}$, mitotic metaphase spindle MT became more and more condensed, even emerged adhesion phenomenon among MTs (Figs 6C1, C3). During anaphase/telophase, there was a small part of MT absent, and MT fibers were stuck to each other, even forming lumps in the cells under $10 \mu \mathrm{mol} / \mathrm{L} \mathrm{Cd}$ for $48 \mathrm{~h}$ (Figs 6D1, D3). Phragmoplast could not be formed due to damage of the mitotic spindle MTs in telophase cells treated with $50 \mu \mathrm{mol} / \mathrm{L} \mathrm{Cd}$ after $48 \mathrm{~h}$ (Figs 6E1, E3), which affected the formation of daughter cells.

\section{qRT-PCR Analysis Results of SmTUA1}

The results of qRT-PCR were shown in Fig. 7. The relative expression level of SmTUA1 in S. matsudana root meristem zone varied with different $\mathrm{Cd}$ concentrations and treatment times. $10 \mu \mathrm{mol} / \mathrm{L} \mathrm{Cd}$ had a slightly toxic effect on the relative expression level of TUA1 during the whole treatment when compared with that in control. There was significant inhibitory effect on the relative 


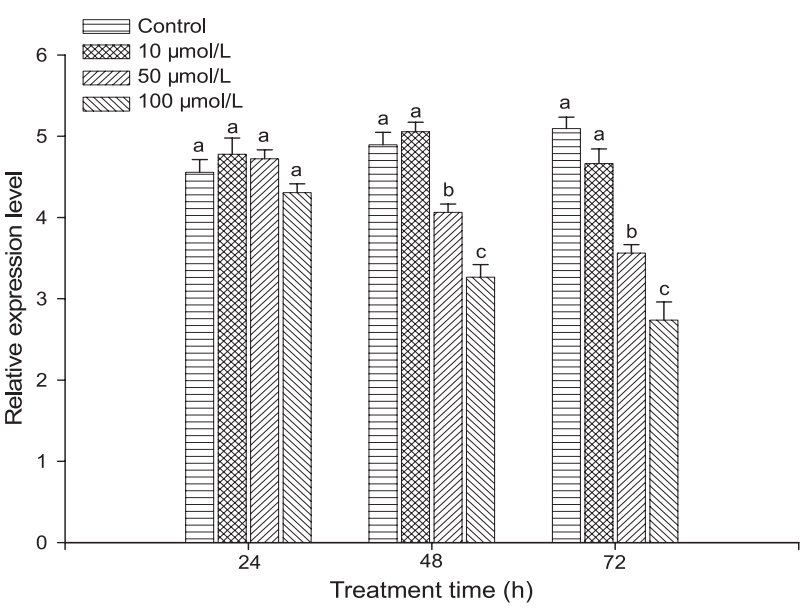

Fig. 7. qRT-PCR expression level of TUA1 in roots of $S$. matsudana exposed to different concentrations of $\mathrm{Cd}$ with different treatment times. Values with different letters differ significantly from each other $(\mathrm{n}=3, \mathrm{P}<0.05$; data are means $\pm \mathrm{SE})$.

expression level of SmTUA1 under 50 and $100 \mu \mathrm{mol} / \mathrm{L}$ Cd stress for 48 and $72 \mathrm{~h}(P<0.05)$.

\section{Discussion}

Cd was one of the most common soil-heavy metal pollutants, which were highly toxic to animals and humans. S. matsudana, with high biomass and strong characteristics of the $\mathrm{Cd}$ tolerance, could be used in phytoremediation of heavy metal-contaminated soil [23]. Plant roots were the most sensitive organ to environmental stresses. Root apical meristems played a key role in the immediate reaction to stress factors by activating signal cascades to the other plant organs. Therefore, understanding cell toxicity mechanisms of $\mathrm{Cd}$ on woody plant root tip cells and their consequences on cell activity and MT cytoskeleton, as performed in the present investigation, were very important for using S. matsudana in the practical application of phytoremediation.

PI staining agent could be used to detect cell damage in plants caused by environmental stress [4]. PI is a very active phenanthridines agent and can pass through the cell wall, but not through the cell membrane. PI can be directly inserted into double-stranded nucleic acid bases to form PIdouble stranded nucleic acid fluorescent compounds that can emit red fluorescence. Therefore, PI can easily enter the dead cells and combine with nuclear DNA molecules, which is an alternative agent for studying cell membrane damage [30]. Here, we can confirm that $\mathrm{Cd}$ has a toxic effect on cell membrane damage in the root tip cells of $S$. matsudana using PI staining. Wang et al. [31] had found that significant red fluorescence in the root cells of barley stressed by heavy metal $\mathrm{Cu}$ was produced by means of PI, and the red fluorescence intensity was enhanced with the extension of treatment time. Shi et al. [4] also observed that the effects of $\mathrm{Cd}$ stress on barley were significant, and the damage and apoptosis of the barley root increased with the extension of treatment time by the PI staining method. These were consistent with the staining results in root tips of $S$. matsudana in this experiment. Therefore, $\mathrm{Cd}, \mathrm{Cu}$, and other heavy metals could affect the plants and accelerate cell damage and apoptosis in a short period of time [3-4, 32]. Compared with barley, S. matsudana had obvious resistance to heavy metal Cd stress. In this experiment, the distribution of red fluorescence was gradually expanded in highly concentrated Cd-treated $S$. matsudana roots for $6 \mathrm{~h}$, and the red fluorescence intensity reached the maximum level until $24 \mathrm{~h}$ of $\mathrm{Cd}$ treatment. In low concentration $\mathrm{Cd}$ solution, the whole root of $S$. matsudana just emitted red fluorescence for nearly $24 \mathrm{~h}$ of treatment, and the red fluorescence intensity was far lower than the fluorescence intensity induced by highconcentration Cd treatment. Thus, the resistance of $S$. matsudana to heavy metal Cd was stronger than that of other herbaceous Poaceae plants, and S. matsudana could reduce cell damage and apoptosis caused by heavy metal $\mathrm{Cd}$ stress. There was intense red flurosence intensity in the apical meristem of 50 and $100 \mu \mathrm{mol} / \mathrm{L} \mathrm{Cd-treated}$ root tips for $24 \mathrm{~h}$ (Figs 2F2, F3) suggesting that meristem cells were severely affected by the high concentration of $\mathrm{Cd}$. In order to further understand the mechanisms of Cd-induced cell toxicity, the effects of $\mathrm{Cd}$ on the microtubule organization in meristem cells of S. matsudana using tubulin immunolabeling and fluorescence microscopy was further investigated.

The cytoskeleton was comprised of the MT array, actin filaments, actin microfilaments, intermediate filaments, etc. [32]. MTs were composed of $\alpha-\beta$ tubulin heterodimers, which assemble in tandem to form the protofilaments of the tube. In the normal differentiated cells, the MT cytoskeleton was very dynamic, and its depolymerization and polymerization were easily affected by environmental factors. The MT cytoskeleton might play an integral role in the signaling events, constantly involved in cell division, cell proliferation, cell differentiation, and cell motility, that enable plants to adapt to stress conditions [33]. Jiang et al. [3] found that MTs of Allium cepa root meristem cells under heavy metal $\mathrm{Pb}$ stress changed significantly with increasing $\mathrm{Pb}$ concentrations and prolonged treatment times, cortical MT appeared depolymerization, adhesion, compaction, and mitotic spindle arrangement appeared disorder, even leading to chromosome abnormal separation, seriously influencing the cell cycle. Zhang et al. [7] studied the effect of aluminium (Al) on masson pine root meristem cell MTs, which was consistent with the research results before [34]. Heavy metals could lead to significant changes in the cytoskeleton, hindering normal cell differentiation and proliferation. The possible mechanism of $\mathrm{Cd}$ on plants were associated with the increased concentrations of calcium ion, inositol triphosphate, protein kinase $\mathrm{C}$, and Cyclic Adenosine monophosphate (cAMP), and the composition and function of MTs were closely related to the balance of intracellular calcium ion or calmodulin activity [33]. Due to the ionic radius of $\mathrm{Cd}$ and calcium 
ions being similar, $\mathrm{Cd}$ combined with some special sites quickly when it went into the cytoplasm, adjusting the concentration of calcium ions in the cytosol and thereby affecting the function of the calcium ion pump on plasma membrane, even hindering the signal transduction of calmodulin and furtherly causing cytoskeletal microtubule depolymerization [35].

Cortical MTs of normal meristematic cells were very abundant during interphase. The data presented in this investigation showed that $\mathrm{Cd}$ disturbed the organization and function of MTs. The increased MT disorder and MT fragments were obvious characteristics at low $\mathrm{Cd}$ concentrations $(10 \mu \mathrm{mol} / \mathrm{L})$, whereas at high concentrations $(100 \mu \mathrm{mol} / \mathrm{L})$ the interphase microtubular network was completely depolymerized, suggesting that MTs were a subcellular target of $\mathrm{Cd}$. A similar phenomenon was observed in that the MTs were disintegrated into short fragments or they completely disappeared in interphase cells of Allium sativum exposed to $\mathrm{Pb}$ and $\mathrm{Cu}[3,32]$. Data from the present investigation indicated that $S$. matsudana was less sensitive than barley, and A. sativum and other crop plants to $\mathrm{Cd}$ stress in MTs arrays of meristematic cells.

During mitosis, Cd disrupted the mitotic spindle and induced chromosomal aberrations. MTs in the mitotic phase were more sensitive than that in interphase, which increased the probability of chromosome aberration, destroyed the normal cell cycle, and increased the number of dead cells. With increased Cd concentrations, the increase of chromosome stickiness and formation of the sticky spindle fibers were closely correlated with the DNA damage since they supplemented each other in recognizing the cell cycle stages. Chromosome stickiness was considered to be a chromatid-type aberration and was attributed to the effect of environmental pollutants on degredation or depolymerization of chromosomal DNA, on DNA condensation, and on entanglement of intertions between chromosomes [3]. The chromosome aberration might be the effect of Cd on DNA and RNA synthesis [7]. It was well known that MTs play key roles in both nuclear division and mitosis in plants. Cd directly or indirectly affected the dynamic condition of MTs, mainly by disturbing MT assembly/disassembly in dividing root tip cells of Salix $[3,32,36]$. Therefore, we speculated that Cd may interact with tubulin and hinder the polymerization process, resulting in defective mitotic spindles.

The similarity of nucleic acid sequences among the eight members of the TUA gene family in S. matsudana reached $73.8-94.1 \%$. The amino acid sequence length of TUA protein was predicted to be $449-451 \mathrm{bp}$. There were highly similar amino acid sequences of the TUA family between $S$. matsudana and other plants, especially with Chosenia arbutifolia (Pall.) A. Skv., Salix Suchowensis W.C. Cheng ex G. Zhu, and Populus trichocarpa [30, 37]. Sui et al. [30] also proved that the relative expression level of SmTUA1 was far higher than for other members, so SmTUA1 was selected for studying the expression level in this investigation. The expression level of SmTUA1 in $S$. matsudana analyzed by qRT-PCR technology was shown in Fig. 7. High concentrations of $\mathrm{Cd}(50$ and $100 \mu \mathrm{mol} / \mathrm{L}$ ) lead to low expressions of SmTUA1, which further proved that the MTs were sensitive to environmental heavy metal stress, which were consistent with the above results by indirect immunofluorescence staining as shown in Figs 5-6.

\section{Conclusions}

Based on the information provided in this article, it is concluded that: $\mathrm{Cd}$ induced cell damage after $3 \mathrm{~h}$ of $10 \mu \mathrm{mol} / \mathrm{L} \mathrm{Cd}$ exposure. This toxic effect increased with increasing $\mathrm{Cd}$ concentration and prolonged treatment. The MT arrays were very sensitive to $\mathrm{Cd}$, and their sensitivity depends on the $\mathrm{Cd}$ concentration and the duration of treatment. Increased MT disorder and fragments of the interphase microtubular network were obvious characteristics, suggesting that MTs were one of subcellular targets of $\mathrm{Cd}$. MTs in the mitotic phase were more sensitive to $\mathrm{Cd}$ than those in interphase. $\mathrm{Cd}$ disrupted the mitotic spindle, closely correlated with chromosome aberrations. High concentrations of $\mathrm{Cd}$ (50 and $100 \mu \mathrm{mol} / \mathrm{L}$ ) led to low expressions of SmTUA1, which further proved that MTs were sensitive to environmental heavy metal stress.

\section{Acknowledgements}

This project was supported by the Natural Science Foundation of Tianjin, China (17JCYBJC22500). The authors wish to express their appreciation to the reviewers for their comments and suggestions.

\section{References}

1. CAO F.B., CHEN F., SUN H.Y., ZHANG G.P., CHEN Z.H., WU F.B. Genome-wide transcriptome and functional analysis of two contrasting genotypes reveals key genes for cadmium tolerance in barley. BMC Genomics 15, 1, 2014.

2. WU H.F., WANG J.Y., LI B.B., OU Y.J., WANG J.R., SHI Q.Y., JIANG W.S., LIU D.H., ZOU J.H. Salix matsudana Koidz tolerance mechanisms to Cadmium: uptake and accumulation, subcellular distribution, and chemical forms. Pol. J. Environ. Stud. 25, 1739, 2016.

3. JIANG Z., QIN R., ZHANG H.H., ZOU J.H., SHI Q.Y., WANG J.R., JIANG W.S., LIU D.H. Determination of $\mathrm{Pb}$ genotoxic effects in Allium cepa root cells by fluorescent probe, microtubular immunofluorescence and comet assay. Plant Soil 383, 357, 2014.

4. SHI Q.Y., WANG J.R., ZOU J.H., JIANG Z., WU H.F., WANG J.Y., JIANG W.S., LIU D.H. Cadmium localization and its toxic effects on root tips of barley. Zemdirbyste 103, $151,2016$.

5. ZOU J.H., YUE J.Y., JIANG W.S., LIU D.H. Effects of cadmium stress on root tip cells and some physiological indexes in Allium cepa var. agrogarum L. Acta Biol. Cracov. Bot. 54, 129, 2012 
6. QIN R., JIANG W.S., LIU D.H. Cadmium can induce alterations in the cellular localization and expression of three major nucleolar proteins in root tip cells of Vicia faba L. Plant Soil 368, 365, 2013.

7. ZHANG H.H., JIANG Z., QIN R., ZHANG H.N., ZOU J.H., JIANG W.S., LIU D.H. Accumulation and cellular toxicity of aluminum in seedling of Pinus massoniana. BMC Plant Biol. 14, 264, 2014.

8. LIU D.H., KOTTKE I. Subcellular localization of cadmium in the root cells of Allium cepa by electron energy loss spectroscopy and cytochemistry. J. Biosciences 29, 329, 2004.

9. JIANG W.S., LIU D.H., XU P. Cd-induced system of defence in the garlic root meristematic cells. Biol. Plantarum 53, 369, 2009.

10. GE W., JIAO Y.Q., SUN B.L., QIN R., JIANG W.S., LIU D.H. Cadmium-mediated oxidative stress and ultrastructural changes in root cells of poplar cultivars. S. Afr. J. Bot. 83, 98, 2012.

11. JIAO Y.Q., GE W., QIN R., SUN B.L., JIANG W.S., LIU D.H. Influence of cadmium stress on growth, ultrastructure and antioxidative enzymes in Populus 2025. Fresen. Environ. Bull. 21, 1375, 2012

12. LIU X.J., SHI Q.Y., ZOU J.H., WANG J.R., WU H.F., WANG J.Y., JIANG W.S., LIU D.H. Chromosome and nucleolus morphological characteristics in root tip cells of plants under metal stress. Fresen. Environ. Bull. 25, 2419, 2016.

13. ADAMAKIS I.D.S., PANTERIS E., CHERIANIDOU A., ELEFTHERIOU E.P. Effects of bisphenol A on the microtubule arrays in root meristematic cells of Pisum sativum L. Mutat. Res-Gen. Tox. En. 750, 111, 2013.

14. BAGNIEWSKA-ZADWORNA A. The root microtubule cytoskeleton and cell cycle analysis through desiccation of Brassica napus seedlings. Protoplasma 233, 177, 2008.

15. GZYL J., CHMIELOWSKA-BĄK J., PRZYMUSIŃSKI R., GWÓŹDŹ E.A. Cadmium affects microtubule organization and post-translational modifications of tubulin in seedlings of soybean (Glycine max L.). Front. Plant Sci. 6, 937, 2015.

16. PARROTTA L., CRESTI M., CAI G. Accumulation and post-translational modifications of plant tubulins. Plant Biology 16, 521, 2014.

17. BREVIARIO D., GIANİ S., MORELLO L. Multiple tubulins: evolutionary aspects and biological implications. Plant J. 75, 202, 2013.

18. YU Y.L., LI Y.Z., LI L.L., LIN J.X., ZHENG C.C., ZHANG L.Y. Overexpression of PwTUA1, a pollen-specific tubulin gene, increases pollen tube elongation by altering the distribution of a-tubulin and promoting vesicle transport. J. Exp. Bot. 60, 2737, 2009.

19. OAKLEY R.V., WANG Y.S., RAMAKRISHNA W., HARDING S.A., TSAI C.J. Differential expansion and expression of $\alpha$ - and $\beta$-tubulin gene families in Populus. Plant Physiol. 145, 961, 2007.

20. SUI J.K., RAO G.D., ZHANG J.G. Cloning and sequence analysis of $\alpha$-tubulin gene families in Salix matsudana Koidz and S. matsudana var. tortuosa (Vilm.) Rehd. Mol Plant Breeding 14, 2305, 2016.

21. LING T., JUN R., FANGKE Y. Effect of cadmium supply levels to cadmium accumulation by Salix. Int. J. Environ. Sci. Technol. 8, 493, 2011.

22. YANG J.L., LI K., ZHENG W., ZHANG H.Z., CAO X.D., LAN Y.X., YANG C.P., LI C.H. Characterization of early transcriptional responses to cadmium in the root and leaf of Cd-resistant Salix matsudana Koidz. BMC Genomics 16, 705, 2015.
23. ZOU J.H., WANG G., JI J., WANG J.Y., WU H.F., OU Y.J., LI B.B. Transcriptional, physiological and cytological analysis validated the roles of some key genes linked $\mathrm{Cd}$ stress in Salix matsudana Koidz. Environ. Exp. Bot. 134, 116, 2017.

24. DICKINSON N.M., PULFORD I.D. Cadmium phytoextraction using short-rotation coppice Salix: the evidence trail. Environ. Int. 31, 609, 2005.

25. DOS SANTOS UTMAZIAN M.N., WIESHAMME G., VEGA R., WENZEL W.W. Hydroponic screening for metal resistance and accumulation of cadmium and zinc in twenty clones of willows and poplars. Environ. Pollut. 148, 155, 2007.

26. KACÁlKOVÁ L., TLUSTOŠ P., SZÁKOVÁ J. Phytoextraction of risk elements by willow and poplar trees. Int. J. Phytoremediat. 17, 414, 2015.

27. YANG J.L., YI J., YANG C.P., LI C.H. Agrobacterium tumefaciens-mediated genetic transformation of Salix matsudana Koidz. using mature seeds. Tree Physiol. 33, 628, 2013.

28. WU H.F., WANG J.Y., OU Y.J., LI B.B., JIANG W.S., LIU D.H., ZOU J.H. Cadmium uptake and localization in roots of Salix matsudana Koidz. Fresen. Environ. Bull. 25, 2700, 2016.

29. WAN X.M., LEI M., YANG J.X. Two potential multi-metal hyperaccumulators found in four mining sites in Hunan Province, China. Catena. 148, 67, 2017.

30. LIAO T.T., SHI Y.L., JIA J.W., WANG L. Sensitivity of different cytotoxic responses of Vero cells exposed to organic chemical pollutants and their reliability in the biotoxicity test of trace chemical pollutants. Biomed. Environ. Sci. 23, 219, 2010.

31. WANG J.R., SHI Q.Y., ZOU J.H., JIANG Z., WANG J.Y., WU H.F., JIANG W.S., LIU D.H. Cellular localization of copper and its toxicity on root tips of Hordeum vulgare. Fresen. Environ. Bull. 24, 2394, 2015.

32. GARDINER J., OVERALL R., MARC J. Plant microtubule cytoskeleton complexity: microtubule arrays as fractals. J. Exp. Bot. 63, 635, 2012.

33. ELEFTHERIOU E.P., ADAMAKIS I.S., MELISSA P. Effects of hexavalent chromium on microtubule organization, ER distribution and callose deposition in root tip cells of Allium cepa L. Protoplasma 249, 401, 2012.

34. XU P., LIU D.H., JIANG W.S. Cadmium effects on the organization of microtubular cytoskeleton in interphase and mitotic cells of Allium sativum. Biol. Plant. 53, 387, 2009

35. LIU D.H., XUE P., MENG Q.M., ZOU J., GU J.G., JIANG W.S. $\mathrm{Pb} / \mathrm{Cu}$ effects on the organization of microtubule cytoskeleton in interphase and mitotic cells of Allium sativum L. Plant Cell. Rep. 28, 695, 2009.

36. RASMUSSEN C.G., WRIGHT A.J., MÜLLER S. The role of the cytoskeleton and associated proteins in determination of the plant cell division plane. Plant J. 75, 258, 2013.

37. RAO G.D., ZENG Y.F., HE C.Y., ZHANG J.G. Characterization and putative posttranslational regulation of $\alpha$ - and $\beta$-tubulin gene families in Salix arbutifolia. Sci. Rep. 6, 19258, 2016.

38. LIVAK K.J., SCHMITTGEN T.D. Analysis of relative gene expression data using real-time quantitative PCR and the ${ }^{2-\Delta \Delta} \mathrm{CT}$ method. Methods 25, 402, 2001. 